\title{
Historical-Genetic Features in Rural Settlement System: A Case Study from Mogilev District (Mogilev Oblast, Belarus)
}

\author{
Elena Gorbenkova ${ }^{1, *(\mathbb{D})}$ and Elena Shcherbina ${ }^{2}$ \\ 1 Highways Department, Belarusian-Russian University, 212000 Mogilev, Belarus \\ 2 Urban Planning Department, Moscow State University of Civil Engineering, 129337 Moscow, Russia; \\ ev.scherbina@yandex.ru \\ * Correspondence: gorbenkowa@yandex.ru; Tel.: +375-29-277-7335
}

Received: 18 April 2020; Accepted: 21 May 2020; Published: 21 May 2020

\begin{abstract}
Settlement system development is currently one of the basic objectives in land use planning, which is significant for Belarus, as it is the most urbanized country in the European region. Historical-genetic analysis is the most effective approach for studying the transformational changes in settlement systems. The research was aimed at analyzing the transformation peculiarities in the rural settlement system of Belarus. The core of the methodological basis lies in general scientific methods (systematic approach, historicism approach, historical-genetic method) and special interdisciplinary methods (cartographic analysis using GIS software). Historical-genetic analysis made it possible to identify the most significant historical periods in the formation of the rural settlement system in Belarus: pre-revolutionary, Soviet and recent. For each period, the pattern and spatial configuration of the rural settlement system were analyzed. Spatial changes in settlement pattern were highlighted: polarization, increasing the share and the population number of the "largest" settlements, the decreasing of "large" and "medium-sized" settlements and the degradation of "small" settlements. As a result, two types of rural settlement transformation were identified: "development" and "degradation". Three ways of spatial configuration of the rural settlement system were identified: "relocation to city", "relocation to the center of the settlement system" and "relocation to settlement". Directions for future research are linked with conceptualizing the model of the spatial-territorial organizing of the rural settlement system.
\end{abstract}

Keywords: regional planning; retrospective analysis; rural settlement; settlement pattern; settlement system; spatial configuration; system approach; transformation forms; urbanization

\section{Introduction}

Currently, settlement development problems are extremely important in solving territorial planning goals for countries [1,2] and regions/subregions [3-5]. Actual studies in urban and regional planning are focused on a spatial-temporal development [6-8], the influence of environment-economic drivers [9-11] and socio-demographic drivers [12-14], planning [15-17], historic-cultural components [18-21] and natural environments [22-24], rural settlement transformation [25-27] and modeling rural-urban areas [28-30]. The overarching aim is identifying key drivers of the forming of the settlement system [31,32] that have a historicism property in terms of the systemic approach [33]. Therefore, historical-genetic analysis is one of the adequate methods for investigating the settlement system [34,35].

The rural settlement system is a socio-natural-anthropogenic system [36] developing under the influence of exogenous/external factors (natural, climatic, industrial, infrastructural, etc.), that determine settlement types and forms, and endogenous/internal factors (socioeconomic, managerial, etc.), 
that reveal settlement processes [37-40]. It should be noted that the transformation of the pattern and spatial-functional structure of the rural settlement in Belarus is associated with numerous processes such as industrialization (late XIX century-early XX century); collectivization (1920s); World War II (1939-1945); the Chernobyl disaster (1986) and the USSR collapse (1991) [41,42].

The increasing interest in studying rural settlements in Belarus is caused by the special role of rural settlements in a spatial country development, where agricultural areas cover $1 / 3$ of the total territory and the GDP share of agriculture is about $7 \%$. Currently, Belarus is the most rapidly urbanizing country in the European region [43], so there is a significant impact on the rural settlement structure. It should be noted that the settlement system, due to its specific features, is sensitive to various risks, such as natural, sanitary-epidemiological, anthropogenic and management planning., as confirmed by the difference in forecast [43] (Figure 1) and estimated data (Table 1).

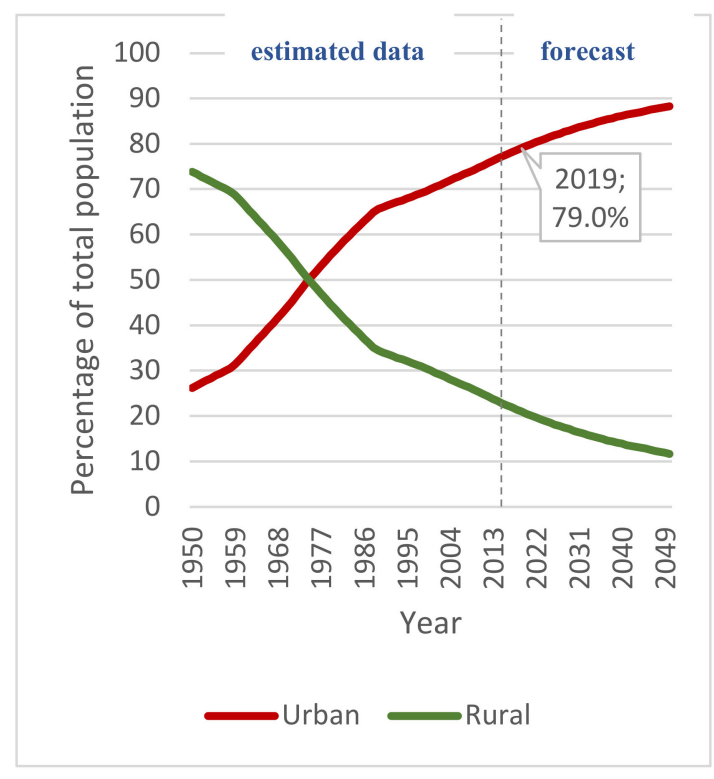

(a)

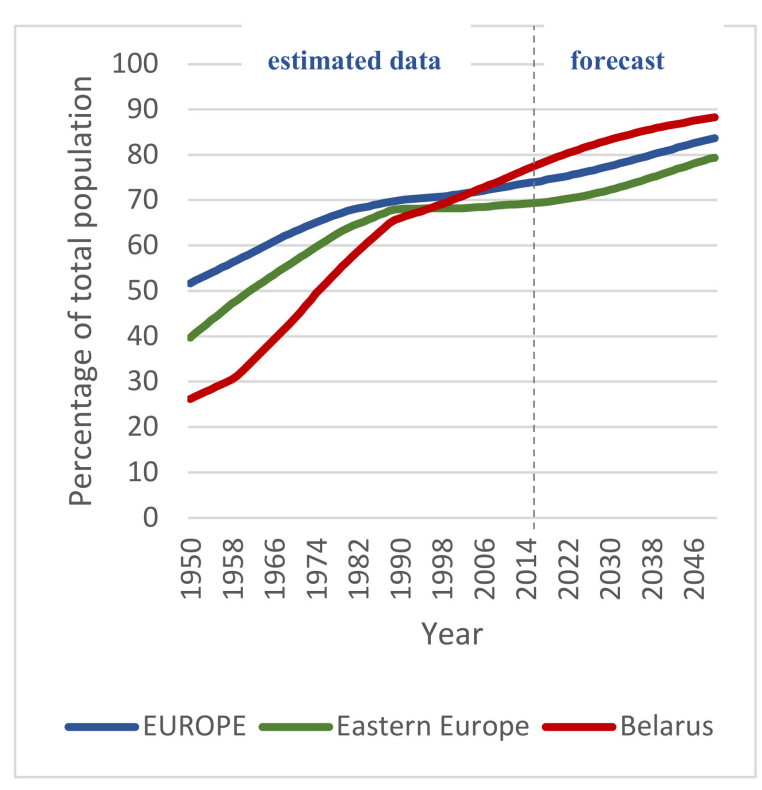

(b)

Figure 1. Percentage of population, from 1950 to 2050, living in (a) urban and rural in Belarus; (b) urban by region and subregion [43].

Table 1. Population census data in Belarus (from the end of the XIX century to the present time).

\begin{tabular}{cccccccccc}
\hline $\begin{array}{c}\text { Population } \\
\text { Census Year }\end{array}$ & $\mathbf{1 8 9 7}$ & $\mathbf{1 9 3 9}$ & $\mathbf{1 9 5 9}$ & $\mathbf{1 9 7 0}$ & $\mathbf{1 9 7 9}$ & $\mathbf{1 9 8 9}$ & $\mathbf{1 9 9 9}$ & $\mathbf{2 0 0 9}$ & $\mathbf{2 0 1 9}$ \\
\hline Urban, \% & 13.5 & 20.8 & 30.5 & 43.3 & 54.9 & 65.4 & 69.3 & 74.3 & 78.4 \\
Rural, \% & 86.5 & 79.2 & 69.5 & 56.7 & 45.1 & 34.6 & 30.7 & 25.7 & 21.6 \\
\hline
\end{tabular}

Urban saturation, as an indicator of social development, is determined by the improvement of industry, cultural and political functions, which is achieved primarily in cities today [44-46]. One of the advantages of rural settlements in Belarus is due to its specific feature. Rural settlements have absorbed the Soviet period genetics: high standards of living were created in agro-towns-modernized centers of rural settlements, formed by converting previously existing central estates to advanced communal farms.

The main research aim was to identify the general features in transformation of the rural settlement system. 


\section{Materials and Methods}

\subsection{Research Area}

The research area was the Mogilev district, the Mogilev oblast, which is located on the eastern side of Belarus. The total area is 1895.4 square kilometers. The administrative center of the Mogilev district is the city of Mogilev, which is administratively not a part of the district. The district is composed of 15 administrative regions (Rural Soviet). There are 276 rural settlements in the district. According to the National Statistical Committee of the Republic of Belarus the population of the district as of 1 January 2019, was 39,667 people. Figure 2 shows the location of the research area.

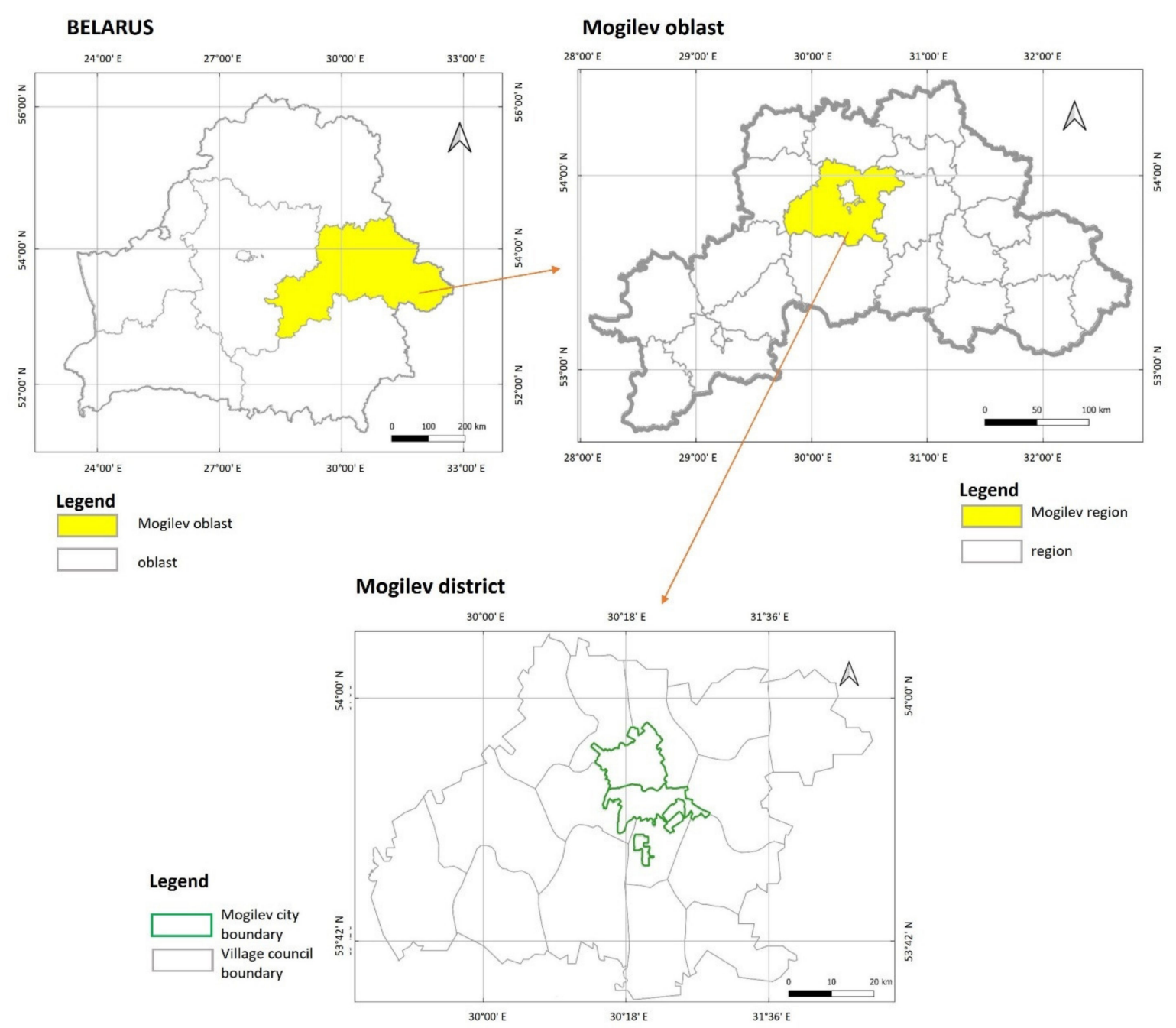

Figure 2. Location of the research area.

\subsection{Research Methods}

\subsubsection{Historicism Approach}

The following hypothesis was formulated in order to solve the research problem: according to a systematic approach, the settlement system meets the historicism principle common to all systems, and historical-genetic modeling allows both studying and forecasting the system development [33].

Historicism, as one of the principles of the system approach, involves the analysis of the system genesis and trends in its development, which is necessary for adequate system functioning. The historicism approach provides deep insight into historical processes. The application of the historicism approach is particularly justified in research detailing the formation of the settlement 
system. The historicism principle involves the analysis of the conditions of the settlement system formation in terms of the cooperative effect of objective and subjective factors that determine the direction and intensity of changes in the settlement pattern. The historicism approach is implemented through a set of methods (historical-genetic, historical-typological, historical-comparative) that provide the synthesis and analysis of changes in the research area. In such a case, the historicism principle can be typified as a modification of system analysis methods, focused on retrospective research $[47,48]$.

For regional planning research, it is important to know the system genesis. The application of the historicism principle allows us to consider the settlement system in specific historical terms and clarify the spatiotemporal dynamics, such as identifying periods and evolution features of the settlement system, which reveal its current status, forecasting the advanced directions for improvement.

\subsubsection{Historical-Genetic Method}

The method basis is linked with a comprehensive analysis of settlement creation and the factors that determine the character of settlement development. The method is based on time sample research in spatial planning and includes three main stages: (1) Preliminary analysis and evaluation of the current settlement pattern. (2) Identifying the changes in regional space planning through time in various socioeconomic periods. (3) Data synthesis and data processing for each period [49].

Stage 1. Preliminary analysis and evaluation the current settlement pattern. This stage includes collecting data on the historical regional development: analyzing old maps, historical databases and statistical data. Consequently, historiographic synthesis allows the presentation of both the sequence of events/factors and the process of forming the main features of the current settlement through time. Identifying the spatiotemporal boundaries for the research area is an overall result of the first stage. Spatial boundaries are assigned by the features of land use planning and management (for example, administrative boundaries). Time boundaries are assigned by the specific features of the research object such as scale, complexity and age. Division into time periods reflects the general and most typical stages in regional planning development.

Stage 2. Identifying the changes in regional space planning. The research is conducted chronologically to identify the most stable elements and features through time/space. When researching each time period, a complex multi-factor analysis is carried out. Besides, it should be noted that historical, socioeconomic and environmental features of the research area are of equal interest. There are four main processes in the second stage: (1) Identifying the planning centers, planning lines and regions for each period. (2) Structuring the settlement system into the main and secondary elements. (3) Establishing a functional and spatial correlation between the structural elements. (4) Identifying key drivers. Thus, the main aim of the second stage is obtaining a complete historical slice for each period. The obtained historical-genetic pattern of the regional settlement comprises a block of complicated data on the research object.

Stage 3. Data synthesis and data processing. The main goals of the third stage are linking the historical slices; identifying the key drivers for the development of the settlement system; and the analysis of the changes in the settlement system. As a result, historical features and trends in the settlement processes for the research object are identified and explained. A summary historical-genetic scheme synthesizes the accumulated data and represents data in a recent cartographic base. The scheme includes regional land zoning by the main periods; regular interconnections between the settlement elements; genetical settlement typology by spatial localization, size and hierarchy in the settlement system; historically formed functional zones and the most stable planning lines.

Consequently, stable trends and regularities in regional spatiotemporal development should be a basis for a predictive model of regional spatial organization. The three main aims are solved using the logical application of previously discussed methodological principles: (i) identifying the genetic basis of the current planning structure and its elements; (ii) the analysis of changes in planning structure within the main stages and phases and (iii) forecasting the development of the regional planning 
structure and its elements. Generally, a holistic vision of the optimal probabilistic development of a settlement system is provided.

This method can be used for retrospective analysis within each hierarchical level of regional planning (from regions and city elements to large regional systems).

\subsubsection{Cartographic Analysis}

The analysis of changes in the spatial configuration and settlement pattern in the area of the Mogilev district has been based on the sources listed in the References, including population census data [50], maps from the years 1826-2020 [51], and the schemes of complex territorial organization (SCTO) of the Mogilev district [52]. Some of cartographic and analytical functionalities of open source GIS (Quantum GIS) were used to reach the research objective: (i) exploring data and composing maps and (ii) creating, capturing, editing, analysis and managing data.

\section{Results and Discussion}

For solving the research aim, three periods in the history of the formation of the Belarus settlement system were identified: (i) pre-revolutionary, (ii) Soviet (1917-1991) and (iii) recent (beyond 1991), which caused the most intense transformation of the rural settlement system. Objectively, such division is due to the political regime changes, from imperialism to socialism, and later to the new socioeconomic stage of creating Belarus as an independent state.

\subsection{Identifying the Changes in Spatial Configuration and Settlement Pattern}

\subsubsection{Pre-Revolutionary Period (Czarist Era)}

The beginning of the pre-revolutionary period (1909) was conditioned by the stability of the existing rural settlement system and data sufficiency.

Within the pre-revolutionary period, the Mogilev district area was a part of the Mogilev Governorate and was divided between Bykhovsky, Goretsky, Mogilev and Chaussky counties. In 1913, the Mogilev county was composed of 13 volosts as centers of the regional settlement system: Belynichskaja (s. Belynichi), Vendrozhskaja (s. Vendrozh), Knjazhickaja (sh. Knjazhicy), Vejnjanskaja (s. Vejnjany), Krugljanskaja (sh. Krugloe), Nezhkovskaja (s. Nezhkov), Pavlovichskaja (s. Pavlovichi), Polykovichskaja (s. Polykovichi), Teterinskaja (sh. Teterin), Tolpechickaja (v. Tolpechicy), Cerkovishhenskaja (s. Cerkovishhe), Chernoruchskaja (s. Chernoruch'e), Shklovskaja (sh. Novyj Shklov). Localities within the current boundaries of the Mogilev district belonged to 12 volosts: Polykovichskaja, Chernevskaja, Gorodishhenskaja, Golenevskaja, Vendorozhskaja, Gluhskaja, Knjazhickaja, Nichiporovskaja, Vejnjanskaja, Grudinovskaja, Tolpechickaja and Gladkovskaja (Appendix A, Figures A1 and A2).

According to census data (1909) there were 295 rural settlements with a population of 60,252 people within the current boundaries of the Mogilev district ("The list of localities of the Mogilev Governorate in 1910"). The average population was 204 people: the minimum -0, the maximum-1361 (Table 2). There were 17 types of rural settlements: Village (43.4\%), Individual farm (8.1\%), Village settlement $(7.5 \%)$, Farm yard $(7.1 \%)$, Grange $(6.8 \%)$, Landed estate $(6.4 \%)$, Hamel $(4.1 \%)$, Settlement $(4.1 \%)$, Zastenok (3,7\%), Outskirts (3.7\%), Shtetl (2\%), Quarter (0.7\%), Outpost (0.7\%), Churchyard $(0.7 \%)$, Monastery $(0.3 \%)$, Farmstead $(0.3 \%)$ and Encampment $(0.3 \%)$. The frequency distribution of the rural localities' proportions for the most popular types is shown in Figure 3, which does not contain the rarest types of settlement to prevent cluttering. 
Table 2. Distribution of rural settlements by population size and household amount in the pre-revolutionary period (within the current boundaries of the Mogilev district).

\begin{tabular}{cccccc}
\hline \multirow{2}{*}{ Rural Settlement Type } & Amount & \multicolumn{2}{c}{ Population Size } & \multicolumn{2}{c}{ Household Amount } \\
\cline { 3 - 6 } & & Total & Average & Total & Average \\
\hline Village & 128 & 39,775 & 311 & 5927 & 47 \\
Individual farm (Chutor) & 24 & 1083 & 46 & 158 & 7 \\
Village settlement (Selo) & 22 & 9591 & 436 & 1446 & 66 \\
Farm yard (Usad'ba) & 21 & 299 & 15 & 41 & 2 \\
Grange (Folvark) & 20 & 504 & 26 & 71 & 4 \\
Landed estate (Imenie) & 19 & 96 & 6 & 23 & 2 \\
Hamel (Selenie) & 12 & 2696 & 225 & 492 & 41 \\
Settlement (Poselok) & 12 & 1470 & 123 & 195 & 17 \\
Zastenok & 11 & 1172 & 107 & 226 & 21 \\
Outskirts (Okolica) & 11 & 834 & 76 & 139 & 13 \\
Shtetl (small town) & 6 & 2278 & 380 & 388 & 65 \\
Quarter (Sloboda) & 2 & 231 & 116 & 41 & 21 \\
Outpost (Vyselok) & 2 & 76 & 38 & 12 & 6 \\
Churchyard & 2 & 15 & 8 & 4 & 2 \\
Monastery & 1 & 118 & 118 & 18 & 18 \\
Farmstead (myza) & 1 & 14 & 14 & 4 & 4 \\
Encampment & 1 & 0 & 0 & 1 & 1 \\
\hline
\end{tabular}

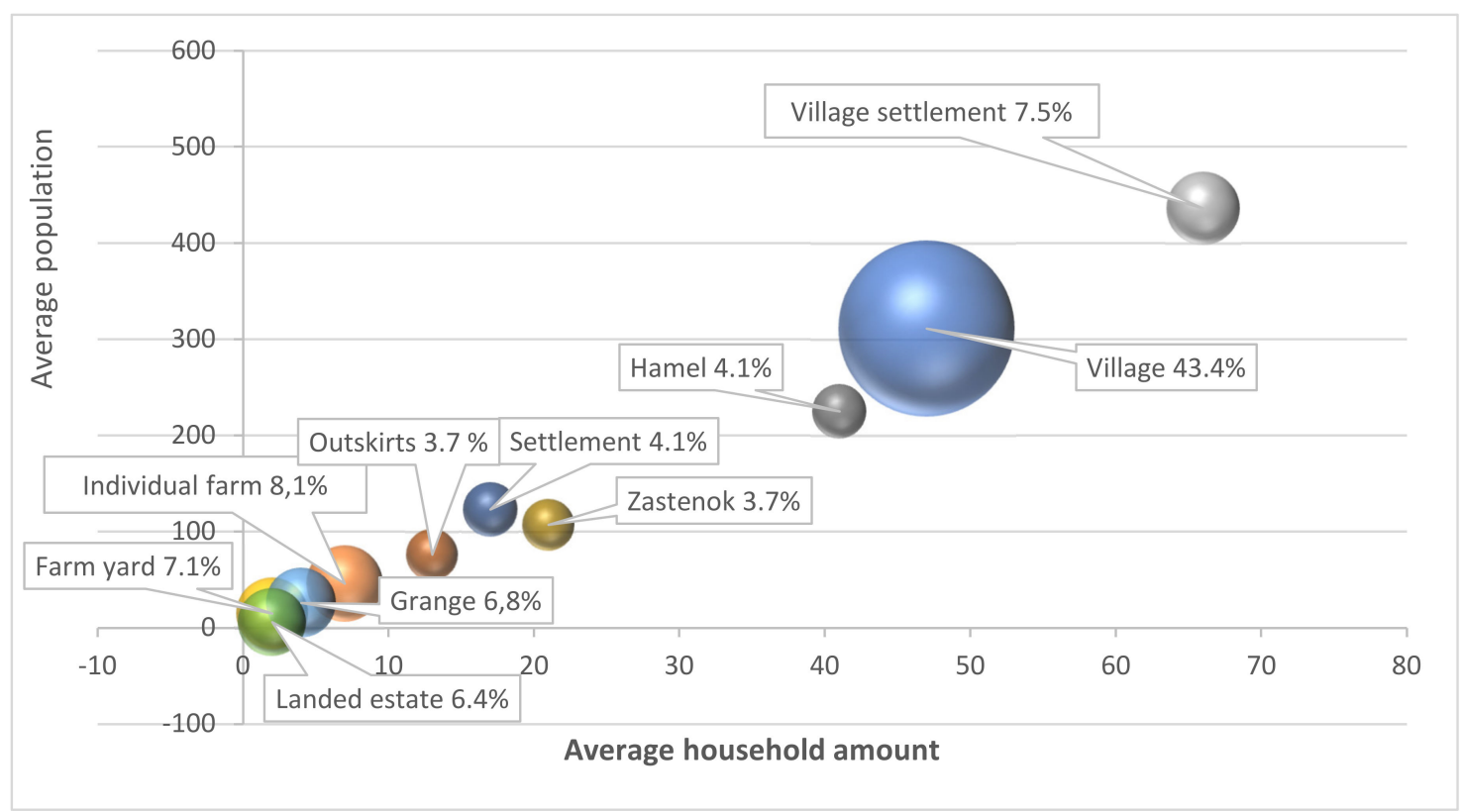

Figure 3. Distribution of rural settlements by size/share in the pre-revolutionary period (within the current boundaries of the Mogilev district).

What is important to notice is that about $10 \%$ of the rural population lived in "small" (less than 100 people) and the "largest" settlements (more than 1000 people). About $1 / 3$ of the rural population lived in "large" (from 500 to 1000 people) settlements. The largest share (almost $60 \%$ of the rural population) lived in "medium" (from 100 to 500 people) settlements. The most typical were "medium-sized" (more than 50\%) and "small" settlements (about 1/3 of the total amount), while the share of "largest" and "large" was respectively $12 \%$ and $1 \%$ (Tables 3-5). 
Table 3. Population and rural settlement amount (in absolute units) within the current boundaries of the Mogilev district from 1909 to 2018.

\begin{tabular}{ccccccccccc}
\hline $\begin{array}{c}\text { Rural Settlement } \\
\text { Type }\end{array}$ & \multicolumn{4}{c}{ Population } & \multicolumn{5}{c}{ Rural Settlement Amount } \\
\cline { 2 - 10 } & $\mathbf{1 9 0 9}$ & $\mathbf{1 9 5 9}$ & $\mathbf{1 9 9 0}$ & $\mathbf{2 0 0 7}$ & $\mathbf{2 0 1 8}$ & $\mathbf{1 9 0 9}$ & $\mathbf{1 9 5 9}$ & $\mathbf{1 9 9 0}$ & $\mathbf{2 0 0 7}$ & $\mathbf{2 0 1 8}$ \\
\hline $\begin{array}{c}\text { Largest } \\
\text { (more than 1000) } \\
\text { Large }\end{array}$ & 3621 & 6321 & 12,201 & 14,909 & 21,685 & 3 & 4 & 8 & 9 & 10 \\
$\begin{array}{c}\text { from 500 to 1000) } \\
\text { Medium }\end{array}$ & 16,564 & 14,726 & 8511 & 8654 & 5495 & 24 & 18 & 12 & 14 & 9 \\
$\begin{array}{c}\text { (from 100 to 500) } \\
\quad \text { Small }\end{array}$ & 36,783 & 40,586 & 25,402 & 13,969 & 14,383 & 138 & 160 & 113 & 61 & 57 \\
$\begin{array}{c}\text { (less than 100) } \\
\text { Total }\end{array}$ & 3284 & 10,200 & 6626 & 6030 & 4929 & 130 & 205 & 152 & 193 & 203 \\
\hline & 60,252 & 71,833 & 52,740 & 43,562 & 46,492 & 295 & 387 & 285 & 277 & 279 \\
\hline
\end{tabular}

Table 4. Population and rural settlement amount (in relative units) within the current boundaries of the Mogilev district from 1909 to 2018.

\begin{tabular}{cccccccccccc}
\hline $\begin{array}{c}\text { Rural Settlement } \\
\text { Type }\end{array}$ & \multicolumn{4}{c}{ Population, \% } & \multicolumn{5}{c}{ Rural Settlement Amount, \% } \\
\cline { 2 - 9 }$y$ & $\mathbf{1 9 0 9}$ & $\mathbf{1 9 5 9}$ & $\mathbf{1 9 9 0}$ & $\mathbf{2 0 0 7}$ & $\mathbf{2 0 1 8}$ & $\mathbf{1 9 0 9}$ & $\mathbf{1 9 5 9}$ & $\mathbf{1 9 9 0}$ & $\mathbf{2 0 0 7}$ & $\mathbf{2 0 1 8}$ \\
\hline $\begin{array}{c}\text { Largest } \\
\text { (more than 1000) }\end{array}$ & 6.0 & 8.8 & 23.1 & 34.2 & 46.6 & 1.0 & 1 & 2.8 & 3.2 & 3.6 \\
$\begin{array}{c}\text { Large } \\
\text { (from 500 to 1000) }\end{array}$ & 27.5 & 20.5 & 16.1 & 19.9 & 11.8 & 8.1 & 4.7 & 4.21 & 5.05 & 3.23 \\
$\begin{array}{c}\text { Medium } \\
\text { (from 100 to 500) }\end{array}$ & 61.0 & 56.5 & 48.2 & 32.1 & 30.9 & 46.8 & 41.3 & 39.6 & 22.0 & 20.4 \\
$\begin{array}{c}\text { Small } \\
\text { (less than 100) }\end{array}$ & 5.5 & 14.2 & 12.6 & 13.8 & 10.6 & 44.1 & 53 & 53.3 & 69.7 & 72.8 \\
$\quad$ Total & 100 & 100 & 100 & 100 & 100 & 100 & 100 & 100 & 100 & 100 \\
\hline
\end{tabular}

Table 5. Changes in the average population size of rural settlements within the current boundaries of the Mogilev district from 1909 to 2018.

\begin{tabular}{cccccc}
\hline \multirow{2}{*}{ Rural Settlement Type } & \multicolumn{5}{c}{ Average Population Size } \\
\cline { 2 - 6 } & $\mathbf{1 9 0 9}$ & $\mathbf{1 9 5 9}$ & $\mathbf{1 9 9 0}$ & $\mathbf{2 0 0 7}$ & $\mathbf{2 0 1 8}$ \\
\hline Largest (more than 1000) & 1207 & 1580 & 1525 & 1657 & 2169 \\
Large (from 500 to 1000) & 691 & 818 & 709 & 618 & 611 \\
Medium (from 100 to 500) & 267 & 253 & 225 & 229 & 252 \\
Small (less than 100) & 26 & 50 & 44 & 31 & 24 \\
\hline
\end{tabular}

\subsubsection{Soviet Period}

The Soviet period started with the conurbation of the Mogilev city and can be considered as the beginning of urbanization, due to the industrial development in the Belorussian Soviet Socialist Republic (BSSR) and a new economic policy. For example, some villages in Polykovichy, Knyazhicy and Veina volosts were forcibly included in the boundaries of the Mogilev city according to the government resolution in 1921 (individual farm Polovinnyj Log, Brody, Holmy, 1st Tishovka, 2nd state farm Krasnopol'e, Mashekovka). At the same time, a number of villages (Maly Pechersk, Karabanovka, Zatishye, Gorki, Khutor Gorodshchina) were left within the county boundaries. It is interesting to note that a bit later, in 1935, a number of villages were delineated as separate settlements (1st Tishovka, Polovinny Log, Krasnopolye, Brody, Holmy) (Appendix A, Figure A3). Later, some settlements disappeared from the maps of the Mogilev county/district. Thus, the Korobanovka village disappeared, nowadays there are only two similarly named streets (Verhnjaja Karabanovka, Nizhnjaja Karabanovka). The Popovka village was located along the current Dimitrov Ave in pre-war times. The Davydovka village became a part of the Mogilev city developed during the Soviet period and is now known 
unofficially as "Abyssinia settlement". The Titovka village was located at the city outskirts along the Bykhov highway. Lupolovo shtetl became a part of the city as a result of the joining the similarly named district in 1931 (Appendix A, Figure A4).

Urbanization was extremely intensive in BSSR in the post-war period (since the mid-1950s), due to socioeconomic, historical, natural and political influence. The fast-paced urbanization was primarily caused by lobbying for a new industrial location in BSSR along with a labor force intake. Therefore, the Grebenevo village disappeared in the beginning of the 1970s. The village territory was occupied by the largest chemical enterprise in Europe (Mogilev synthetic fiber plant), whose area was included in the city boundaries.

Previously, there was the Gorki individual farm and the Gorki village in the southern part of the Mogilev city. Today there is a microdistrict "Rabochij poselok". The Holmy village was previously located to the east of Mogilev and became a city area later. There was the Dubenets village to the north in pre-war times. Later, the village area became the microdistrict called "8th brick". There is a residential area of the KSI (silicate products enterprise) nowadays. Nearby there is the Solominka microdistrict, which was built on the territory of the similarly named village. The Kazimirovka microdistrict developed from 1978 to the recent period in the western part of the Mogilev city along the Minsk highway within the territory of the similarly named village. The Sputnik microdistrict located on the territory of the Gorodshchina individual farm was actively developed in the post-Soviet period (Appendix A, Figure A5).

The Soviet period includes several stages related to structural changes in rural settlement: communization and collectivization (1920s-1930s), followed by individual farm rehabilitation; industrialization (1930s-1940s and 1950s-1970s); World War II (1941-1945) and the Chernobyl disaster (1986).

The course of settlement consolidation and individual farm rehabilitation was taken during the stage of collectivization and communization (1920s-1930s), when more than 80 new rural settlements were formed within the current boundaries of the Mogilev district. It should be noted that the population of the district decreased in the post-war period due to military operations within the territory of BSSR. Thus, about $70 \%$ of residential buildings in 54 settlements (about $1 / 3$ of the total amount in the district) were destroyed from 1942 to 1944, and almost 20\% (10 units) were destroyed completely (Gorodok, Goryany, Dobrosnevichi, Termina, Lunise, Kurgan, Maloe Bushkovo, Nikolaivka, Stashino, Churaevka) [53].

Significant changes occurred in the settlement structure. The largest share $(53 \%)$ belonged to "small" settlements with a population of $14.2 \%$. The share of $56.5 \%$ lived in "middle" settlements $(41.3 \%)$. The share of "large" ones was $4.7 \%$, with a population of $20.5 \%$, and the smallest group was represented by the "largest" settlements (1\%) with a share of the population of $8.8 \%$ (according to the 1959 census) (Table 4). As a result of the Chernobyl disaster, some territories of BSSR were poisoned by nuclear pollution and the relocation of the greater share of the rural population to other settlements followed. Consequently, by the end of the Soviet period (1990), the share of the "largest" settlements was $2.8 \%$, with a population of $23.1 \%$, "large" settlements had $4.21 \%$ and $16.1 \%$, respectively, the share of "medium" settlements was $39.6 \%$ with a population of $48.2 \%$. The largest group was represented by "small" settlements (53.3\%) with a population of $12.6 \%$ (Figure 4 ).

\subsubsection{Recent Period}

During the recent period, the conurbation continued due to the annexation of rural territories. Thus, in the mid-2000s, the Malaya Borovka village and the Dary village (partially) were included in the city boundaries (Appendix A, Figure A6). 


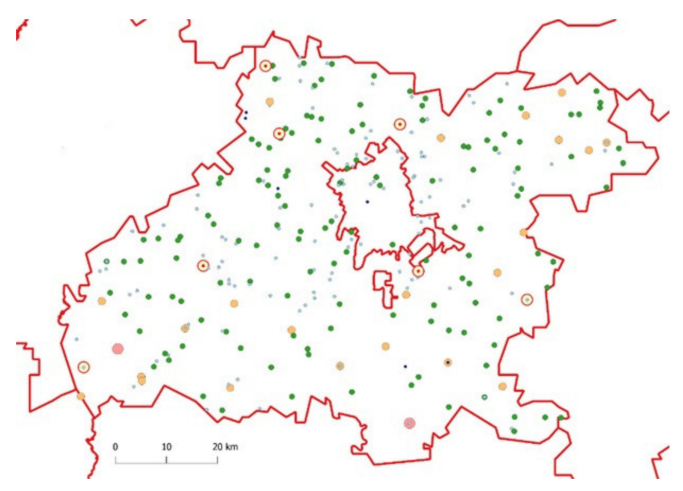

(a)

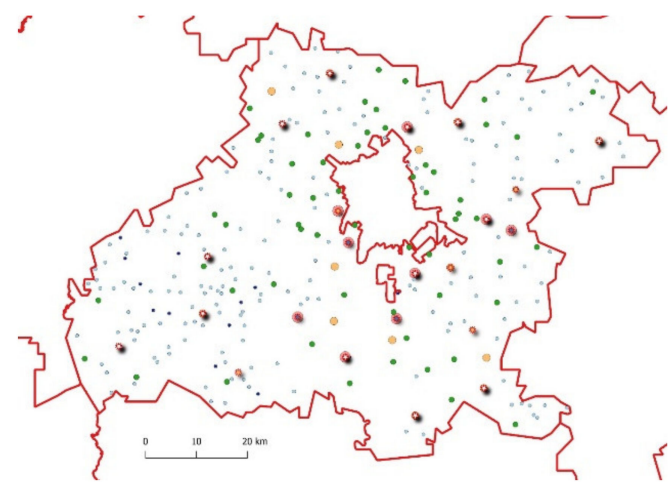

(c)

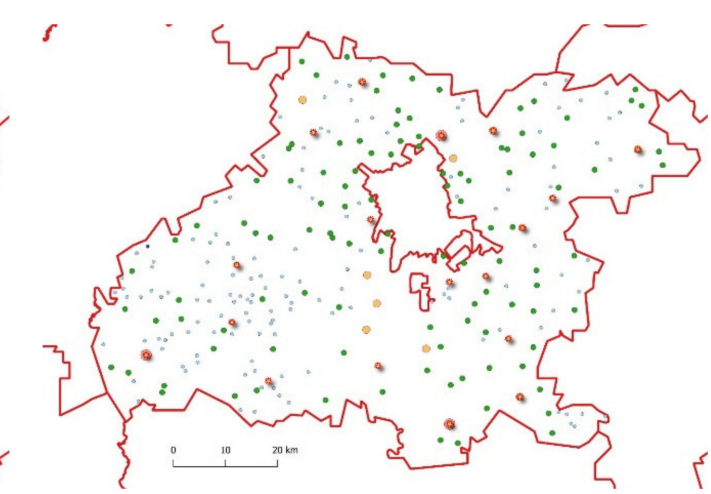

(b)

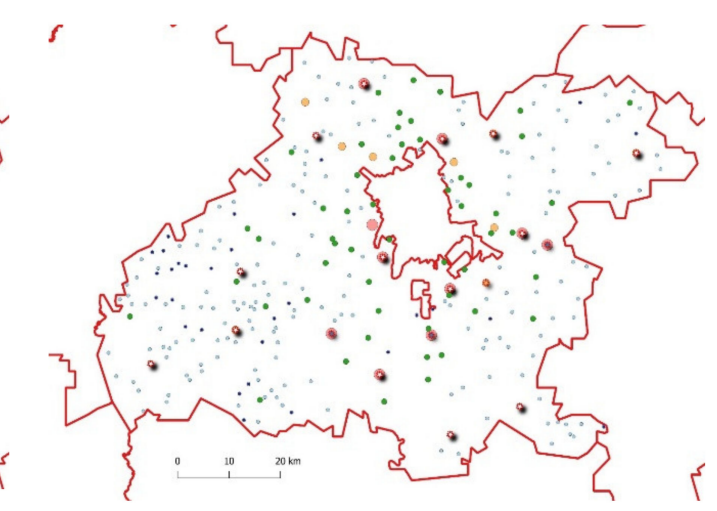

(d)

\section{Legend}
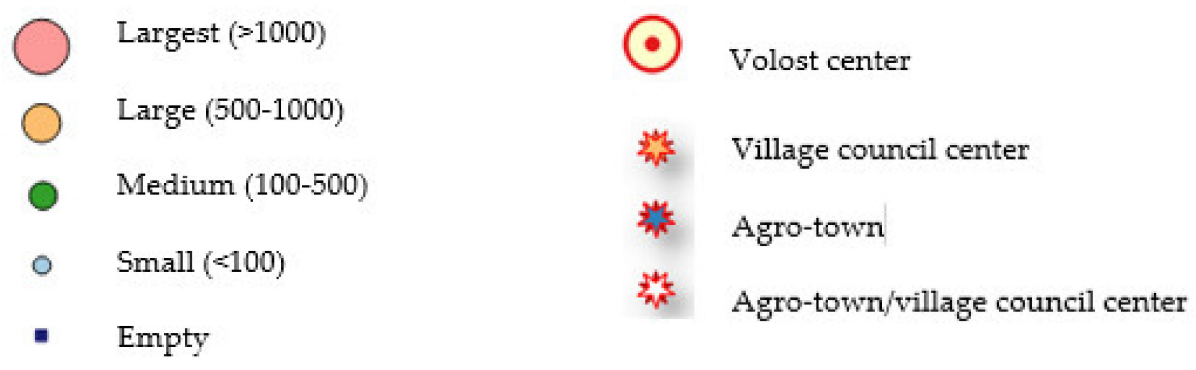

Figure 4. The locality network within the current boundaries of the Mogilev district (a) 1909; (b) 1990; (c) 2007 ; (d) 2018 .

The population decreased in all settlement groups: "small" - from 12.6\% in 1990 to $13.8 \%$ in 2007 and 10.6\% in 2018; "medium"-from $48.2 \%$ in 1990 to $32.1 \%$ in 2007 and 30.9\% in 2018; "large"-from $16.1 \%$ in 1990 to $19.9 \%$ in 2007 and $11.8 \%$ in 2018 . The exception is the "largest" group, where the population has more than doubled since the beginning of the recent period: from $23.1 \%$ in 1990 to $34.2 \%$ in 2007 and $46.6 \%$ in 2018. At the same time, the number of "medium-sized" settlements decreased significantly: from $39.6 \%$ in 1990 to $22 \%$ in 2007 and $20.4 \%$ in 2018; "large" ones-from $4.21 \%$ in 1990 to $5.05 \%$ in 2007 and $3.23 \%$ in 2018. A number of the "largest" ones, from $2.8 \%$ in 1990 to $3.2 \%$ in 2007 and 3.6\% in 2018 and "small" ones, from 53.3\% in 1990 to $69.7 \%$ in 2007 and $72.8 \%$ in 2018, increased (Table 4, Figure 4). The most significant changes occurred at the beginning of the recent period and were linked with is the USSR collapse. It should be noted that the transformation of the rural settlement system reduced with the ratification of the "National plan of rural renewal and development" in 2005. 
The locality network from 1909 to 2018 within the current boundaries of the Mogilev district are shown in Figure 4.

Changes in the density of the rural population from 1909 to 2018 are shown in Figure 5.

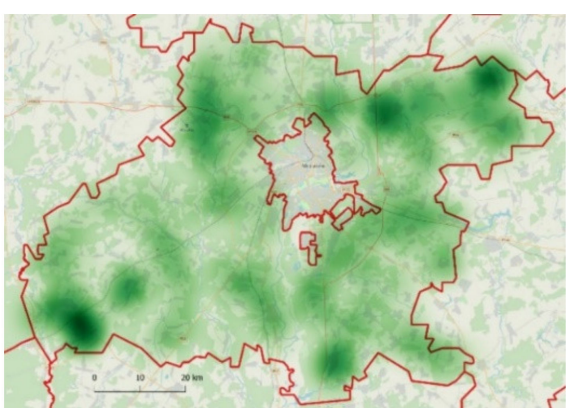

(a)

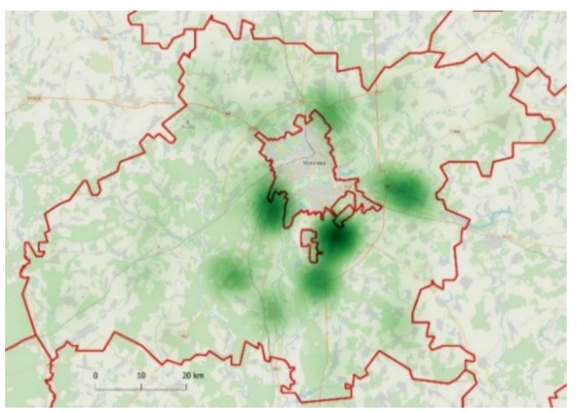

(c)

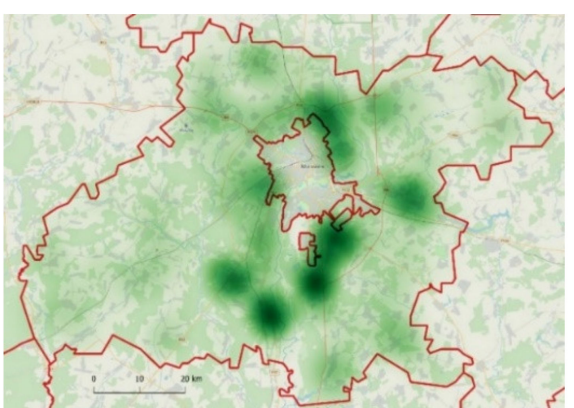

(b)

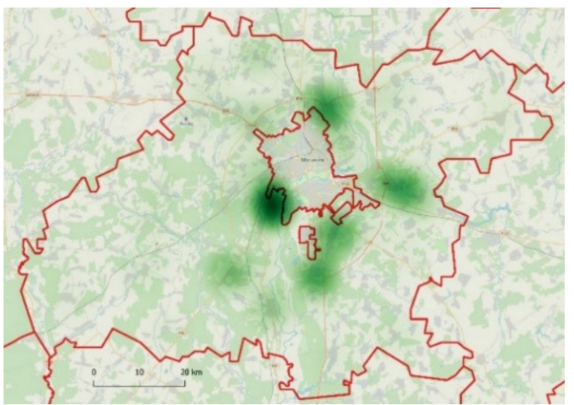

(d)

Figure 5. Rural population density within the current boundaries of the Mogilev district: (a) 1909; (b) 1990; (c) 2007; (d) 2018.

The changes in the rural settlement structure from 1909 to 2018 are shown in Figures 6-8. The key trend is structural polarization, the steady decreasing of "large" settlements and increasing the number of the "largest" settlements; rapidly decreasing the number of "medium-sized" settlements and increasing the number of "small" ones and the population decreasing in all settlement groups except "large" ones.

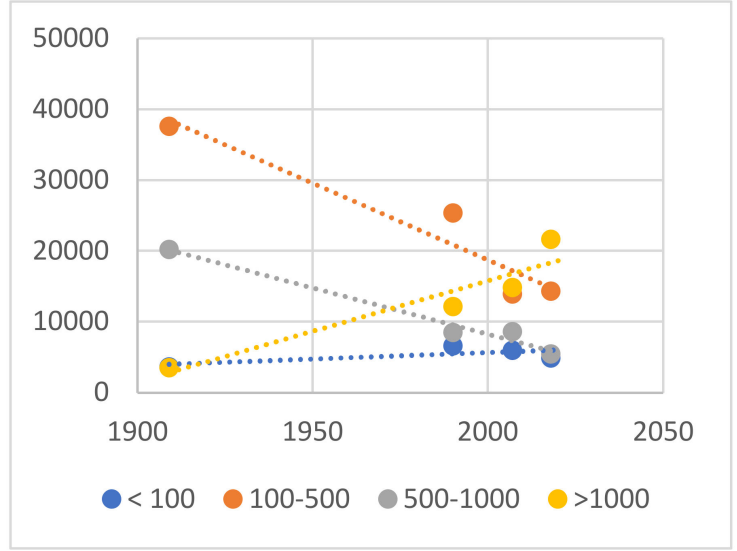

(a)

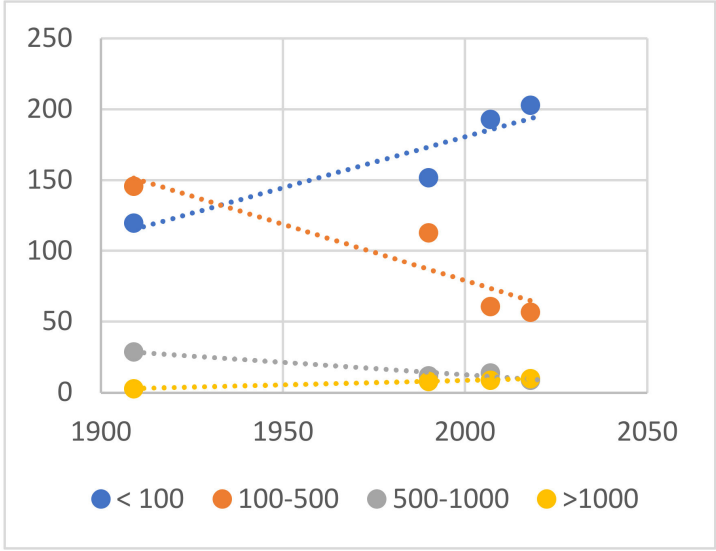

(b)

Figure 6. Changes and trends in the rural settlement system within the current boundaries of the Mogilev district: (a) population; (b) rural settlement amount. 


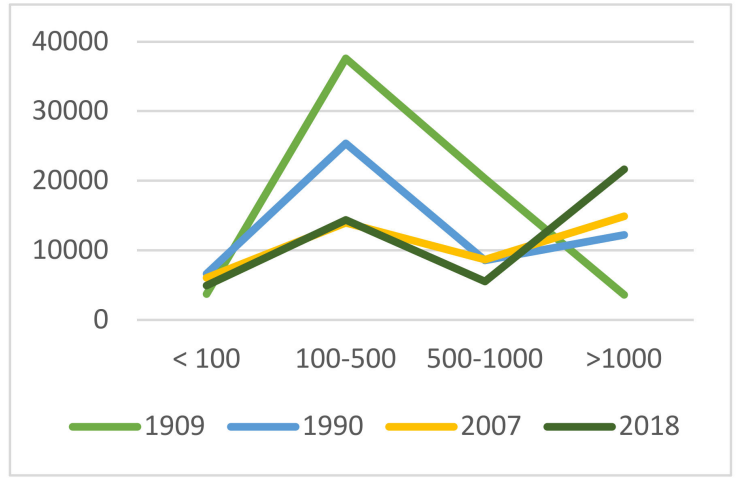

(a)

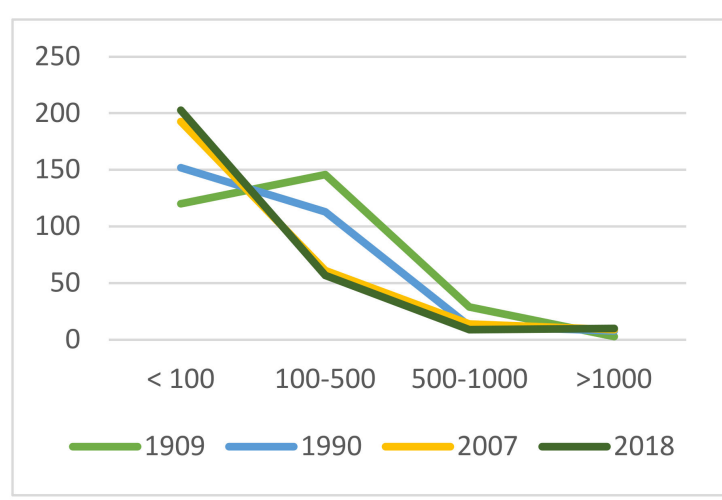

(b)

Figure 7. Structural changes in the rural settlement system of the Mogilev district (in absolute units): (a) population; (b) rural settlement amount.

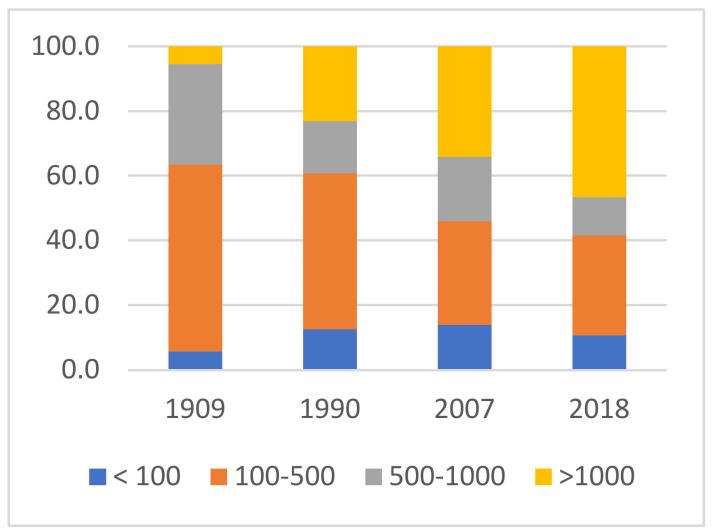

(a)

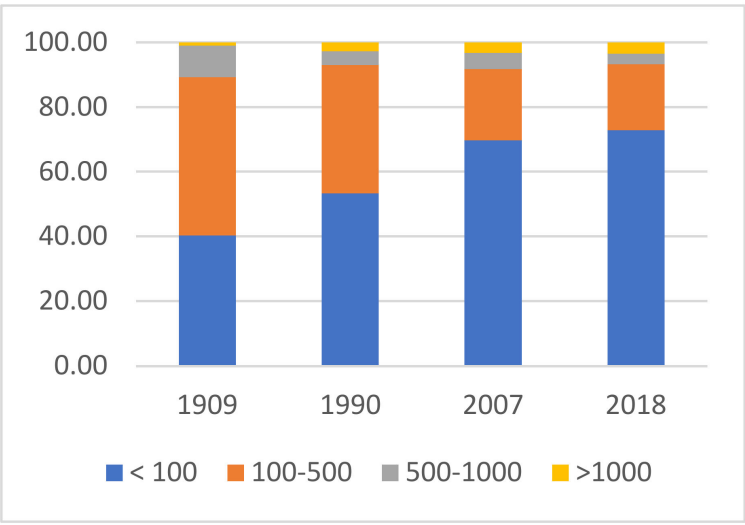

(b)

Figure 8. Structural changes in the rural settlement system of the Mogilev district (in relative units): (a) population; (b) rural settlement amount.

\section{Conclusions}

The current research confirmed the validity of the research hypothesis. The obtained results show the relevance of the historical aspect for the analysis of the settlement system. The conclusions are as follows:

(1) The historical-genetic analysis allowed us to identify three historical periods: pre-revolutionary, soviet and recent, which is significant in the formation of the rural settlement system in Belarus. It should be noted that socioeconomic, ecological and administrative aspects, such as changes in government policy, man-made and natural disasters and ongoing reforms affected the transformation of the settlement system in the research area.

(2) Structural changes in the rural settlement system in Belarus were found between 1909 and 2020. The main trend is network polarization: increasing the share of the "largest" settlements and their population, the decreasing of "large" and "medium-sized" settlements and the degradation of "small" settlements.

(3) Two sample groups of settlement transformation were identified: "development" and "degradation". There are two transformation types in the "development group":

(i) The changeover to "urban settlement" is linked with population growth and industrial growth.

(ii) The changeover to agro-towns is linked with population growth and agro-industrial growth. 
The second group, "degradation", comprises the following transformation forms: (i) Degradation as a result of depopulation. (ii) Disappearance/absorption as a result of city/agglomeration growth.

(4) Three ways of spatial configuration in the rural settlement system were identified. The first way, "relocation to city", comprises the complete/partial relocation of rural residents to the city or conurbation. The second way, "relocation to the center of the settlement system", comprises moving residents to larger/leading settlements (village council center, agro-town) or changing the settlement type. The third way, "relocation to settlement", involves moving residents to current/created settlements, which is linked with settlement elimination as a result of man-made disasters, natural disasters and ongoing reforms.

The findings of this paper can enrich the existing theoretical research on regional planning and can provide guidance for policy makers to encourage the sustainability of settlement patterns. Future research perspectives are linked with conceptualizing the model of the spatial-territorial organizing of the rural settlement system.

Author Contributions: Conceptualization, E.G. and E.S.; methodology, E.G. and E.S.; software, E.G.; validation, E.G. and E.S.; formal analysis, E.G. and E.S.; investigation, E.G. and E.S.; resources, E.G.; data curation, E.G.; writing—original draft preparation, E.G.; writing—review and editing, E.S.; visualization, E.G.; supervision, E.S.; project administration, E.S.; funding acquisition, E.G. and E.S. All authors have read and agreed to the published version of the manuscript.

Funding: This research received no external funding.

Acknowledgments: The authors are very grateful to the editor and anonymous reviewers for constructive comments and suggestions, thanks to whom the article received its final shape.

Conflicts of Interest: The authors declare no conflict of interest.

\section{Appendix A}

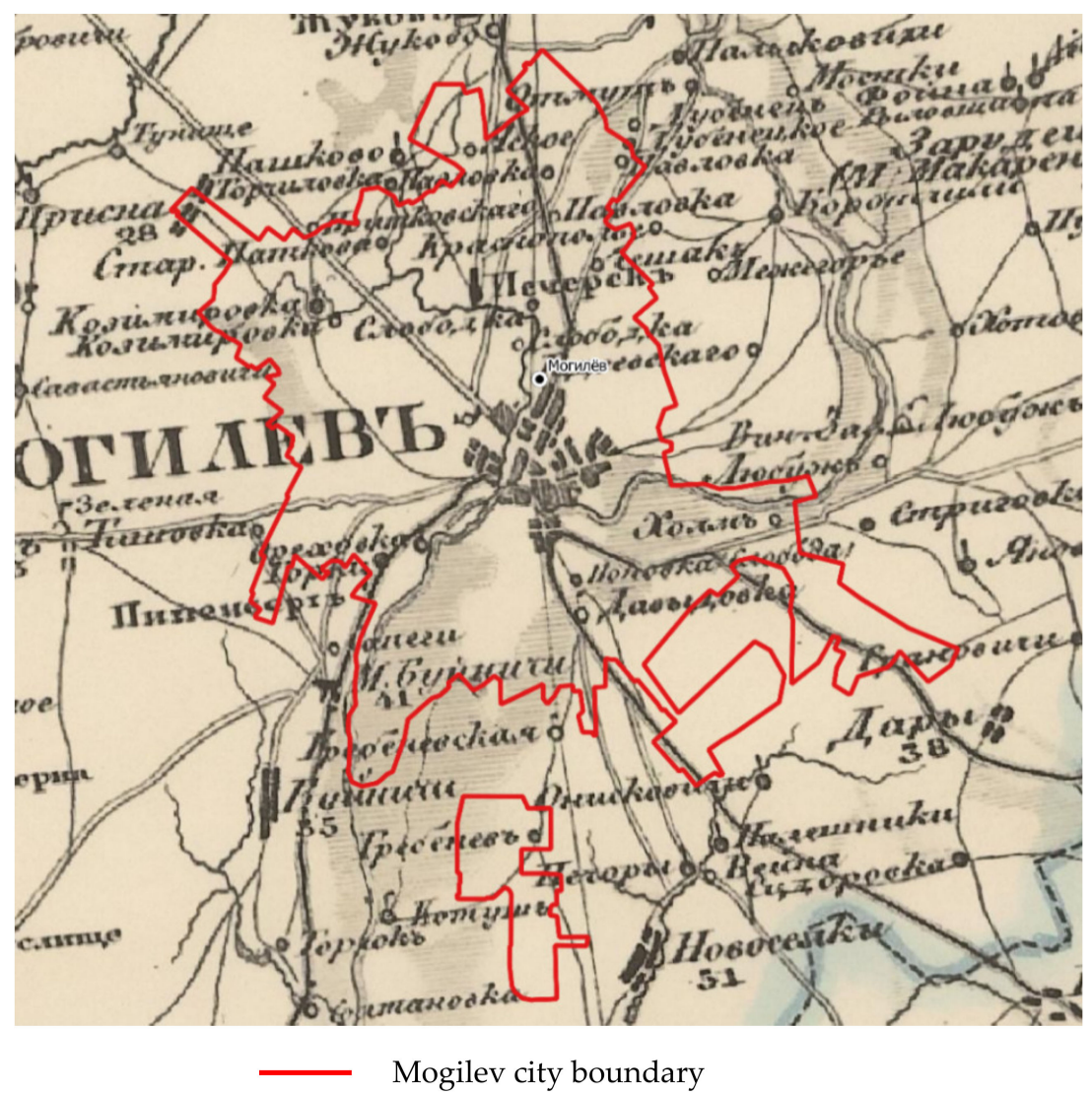

Figure A1. The Mogilev county map tile (1826). 


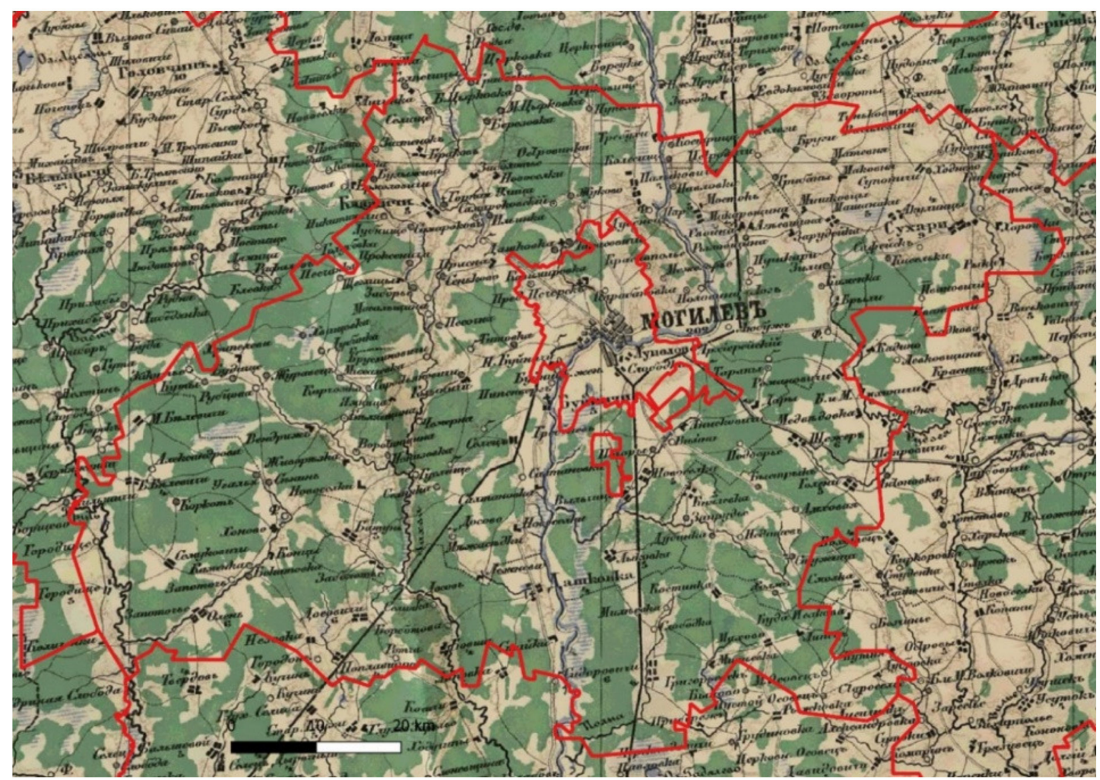

— Mogilev city boundary

Figure A2. The Mogilev Governorate map tile (1871).

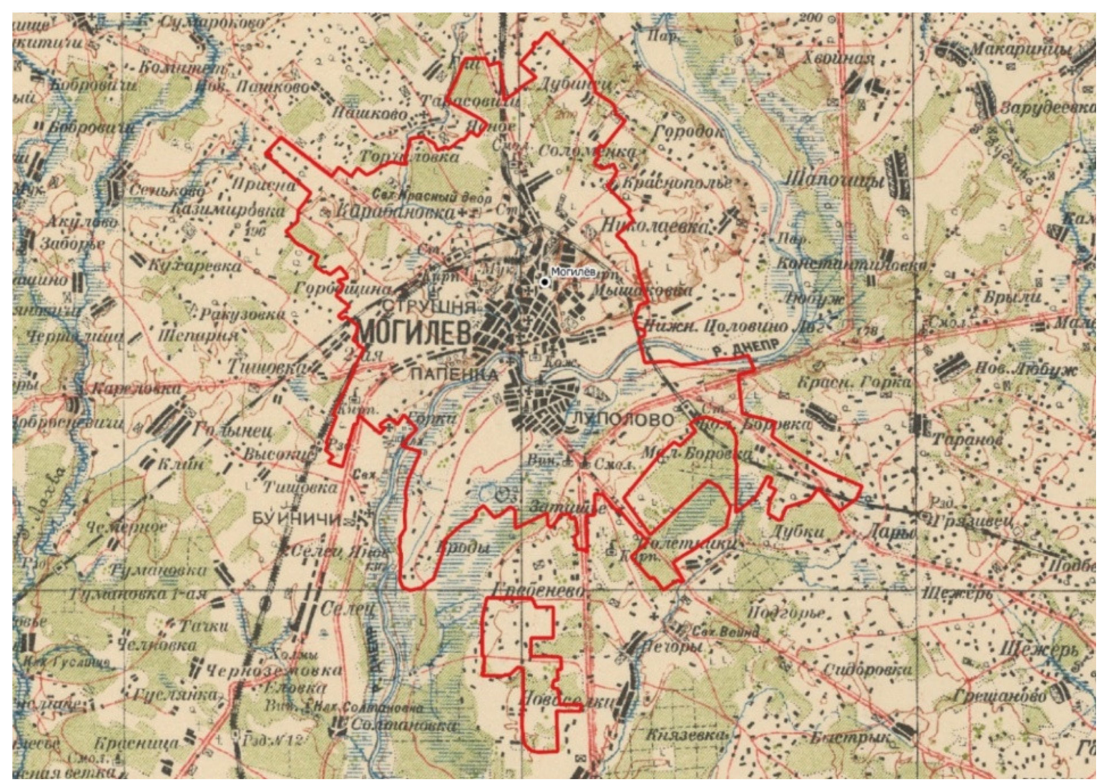

— Mogilev city boundary

Figure A3. The Mogilev district map tile (1935). 


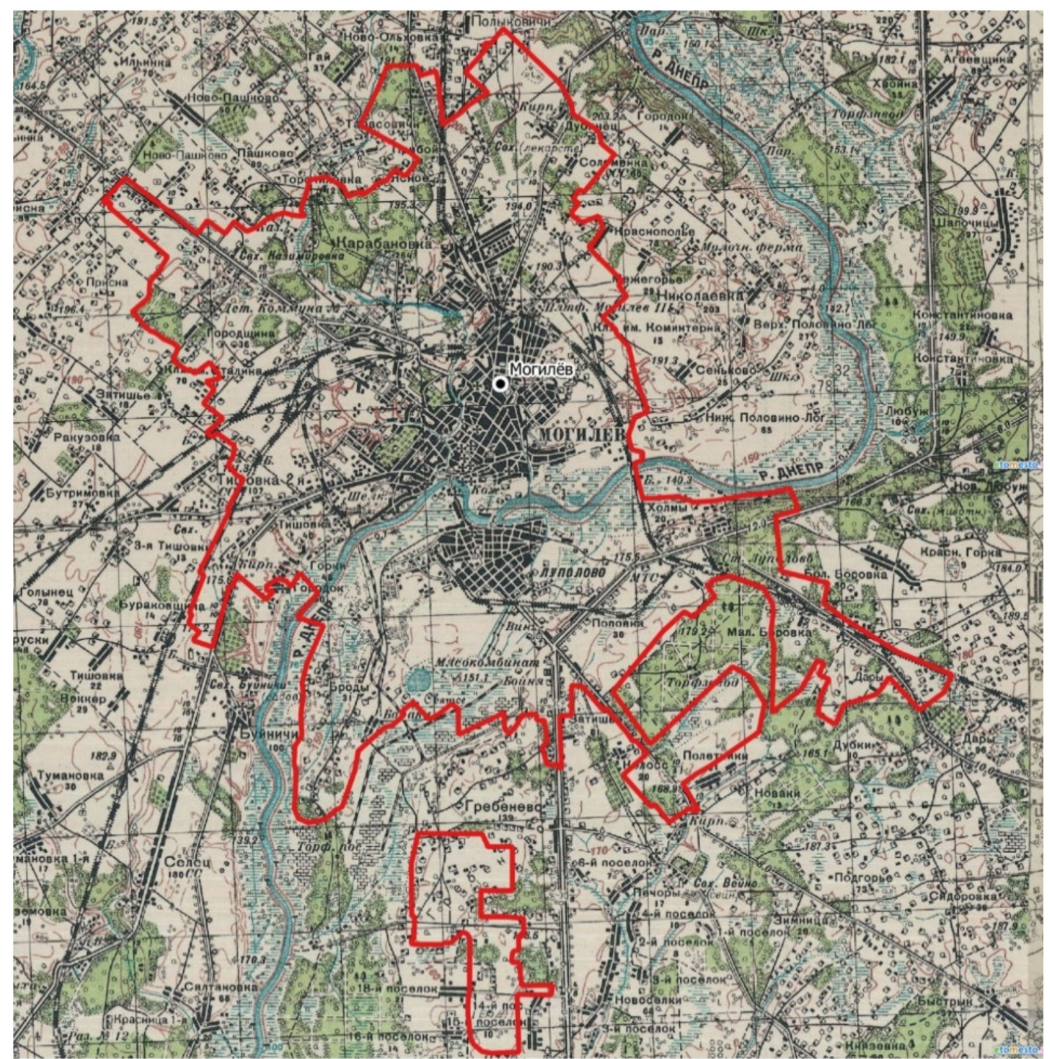

— Mogilev city boundary

Figure A4. The Mogilev district map tile (1941).

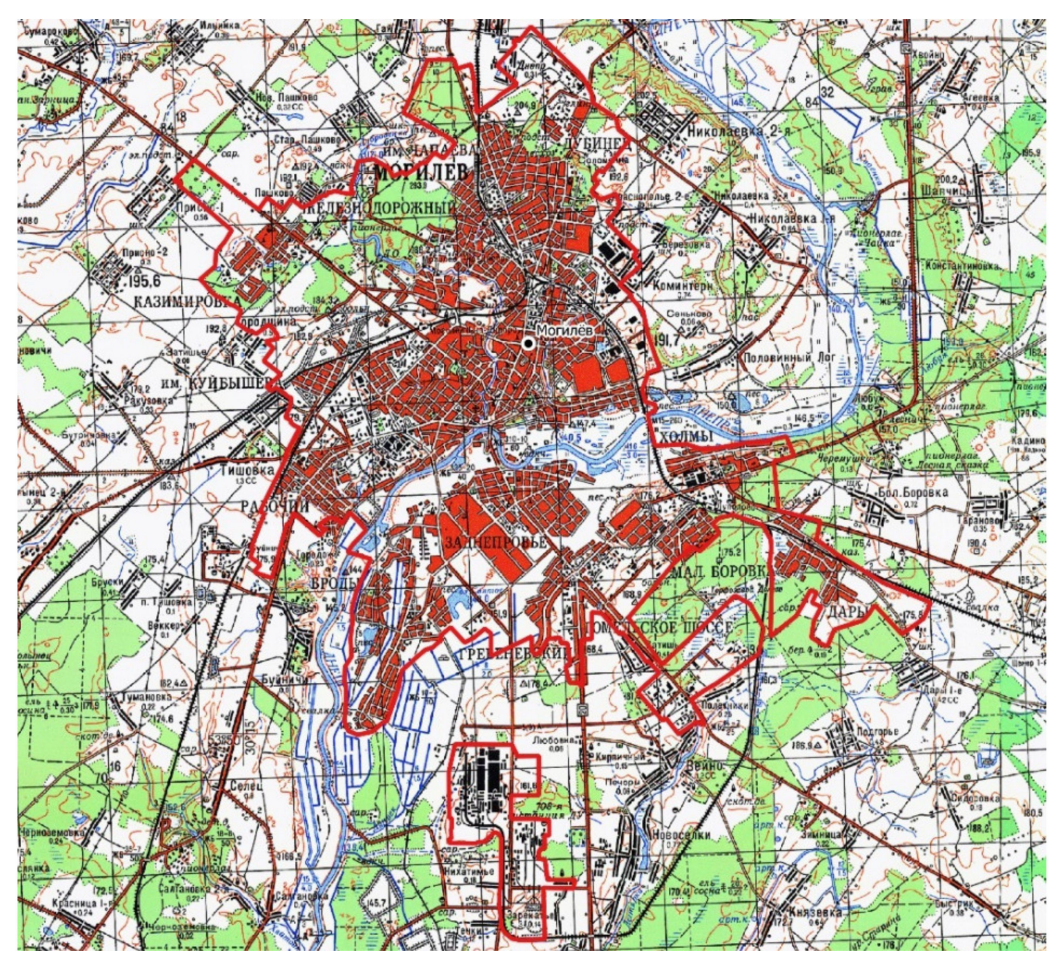

—_ Mogilev city boundary

Figure A5. The Mogilev district map tile (1989). 


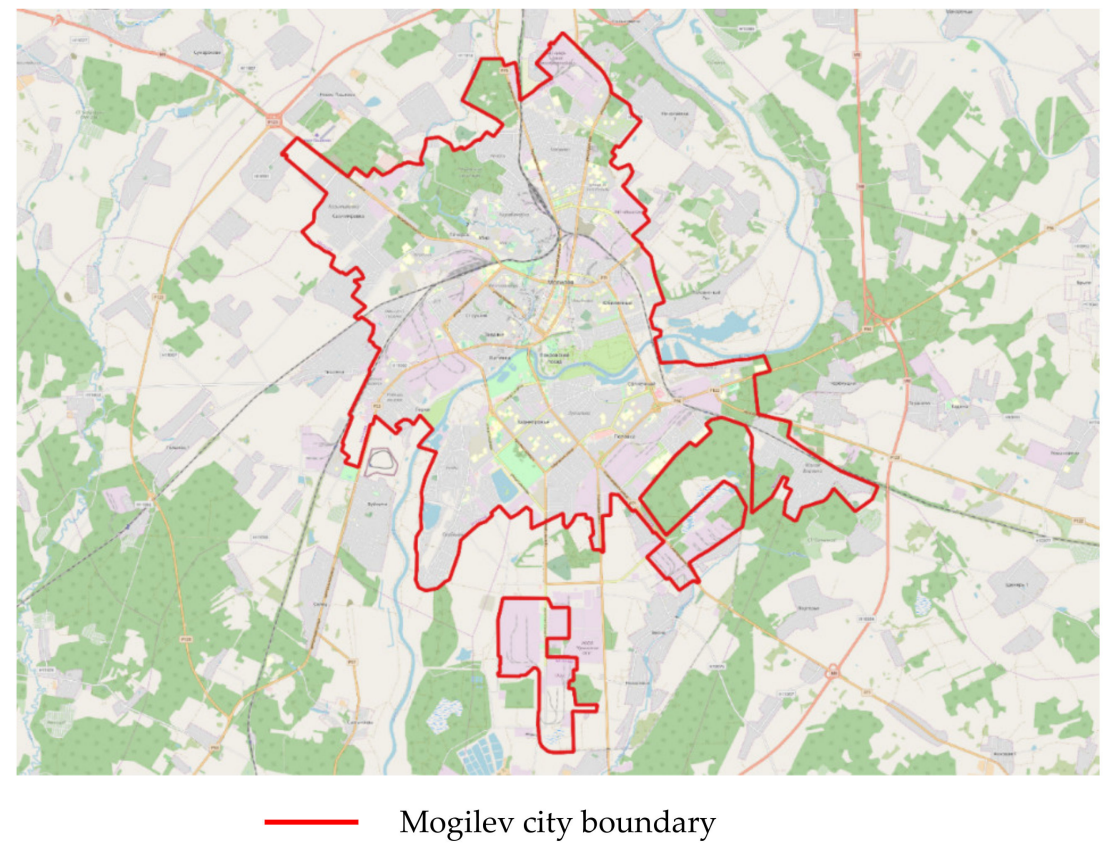

Figure A6. The Mogilev district map tile (2020).

\section{References}

1. Rząsa, K.; Ogryzek, M.; Źróbek, R. The Land Transfer from the State Treasury to Local Government Units as a Factor of Social Development of Rural Areas in Poland. Land 2019, 8, 170. [CrossRef]

2. Jürgenson, E.; Rasva, M. The Changing Structure and Concentration of Agricultural Land Holdings in Estonia and Possible Threat for Rural Areas. Land 2020, 9, 41. [CrossRef]

3. Shubenkov, M.V.; Khomyakov, D.A. Space of the regional agglomerations and re-industrialization. J. Appl. Eng. Sci. 2016, 1, 154-162. [CrossRef]

4. Ilyichev, V.A.; Kolchunov, V.I.; Bakaeva, N.V. Principles of area development strategic planning (the case of the free state of Bavaria). Proc. Mosc. State Univ. Civ. Eng. 2019, 14, 158-168. [CrossRef]

5. Perkova, M.V.; Baklazhenko, E.V.; Vaytens, A.G. Urban conflicts of the Belgorod regional settlement system and its elements. IOP Conf. Ser. Mater. Sci. Eng. 2018, 463, 032014. [CrossRef]

6. Ilvitskaya, S.; Prihodko, V. Innovative technologies in the field of topography, land management, territorial planning, construction and architecture. IOP Conf. Ser. Mater. Sci. Eng. 2018, 365, 022030. [CrossRef]

7. Salvia, R.; Serra, P.; Zambon, I.; Cecchini, M.; Salvati, L. In-Between Sprawl and Neo-Rurality: Sparse Settlements and the Evolution of Socio-Demographic Local Context in a Mediterranean Region. Sustainability 2018, 10, 3670. [CrossRef]

8. Stych, P.; Kabrda, J.; Bicik, I.; Lastovicka, J. Regional Differentiation of Long-Term Land Use Changes: A Case Study of Czechia. Land 2019, 8, 165. [CrossRef]

9. Borisov, M.V.; Bakaeva, N.V.; Chernyaeva, I.V. Normative and technical regulation in the field of urban green space arrangement. Mon. J. Constr. Archit. 2020, 15, 212-222. [CrossRef]

10. Antonić, B.; Djukić, A. Environmentally-Friendly Planning for Urban Shrinkage. IOP Conf. Ser. Earth Env. Sci. 2020, 410, 012084. [CrossRef]

11. Shcherbina, E.V.; Marshalkovich, A.S.; Zotova, E.A. Sustainable development of rural settlements: The importance of environmental factors. Ecol. Urban Areas 2018, 2, 78-83. [CrossRef]

12. Rover, O.J.; De Gennaro, B.C.; Roselli, L. Social Innovation and Sustainable Rural Development: The Case of a Brazilian Agroecology Network. Sustainability 2017, 9, 3. [CrossRef]

13. Cárdenas Alonso, G.; Nieto Masot, A. Towards Rural Sustainable Development? Contributions of the EAFRD 2007-2013 in Low Demographic Density Territories: The Case of Extremadura (SW Spain). Sustainability 2017, 9, 1173. [CrossRef] 
14. Prevolšek, B.; Maksimović, A.; Puška, A.; Pažek, K.; Žibert, M.; Rozman, Č. Sustainable Development of Ethno-Villages in Bosnia and Herzegovina-A Multi Criteria Assessment. Sustainability 2020, 12, 1399. [CrossRef]

15. Danilina, N.V. "Nomadic urbanism"-The modern conception of public areas urban planning. Ecol. Urban Areas 2018, 2, 91-95. [CrossRef]

16. Krčílková, Š.; Janovská, V. Land Tenure as a Factor Underlying Agricultural Landscape Changes in Europe: A Review. Sci. Agric. Bohem. 2016, 47, 68-81. [CrossRef]

17. Zhao, Y.; Leng, H.; Sun, P.; Yuan, Q. A Spatial Zoning Model of Municipal Administrative Areas Based on Major Function-Oriented Zones. Sustainability 2018, 10, 2976. [CrossRef]

18. Esaulov, G.V. On Identity in Architecture and Urban Planning. Acad. Archit. Constr. 2018, 4, 12-18. [CrossRef]

19. Evseeva, E.V.; Ilvitskaya, S.V. Cultural landscape. Archit. Constr. Russ. 2019, 3, 116-117.

20. Agnoletti, M.; Emanueli, F.; Corrieri, F.; Venturi, M.; Santoro, A. Monitoring Traditional Rural Landscapes. The Case of Italy. Sustainability 2019, 11, 6107. [CrossRef]

21. Shcherbina, E.V.; Belal, A.A. The value of historical and cultural heritage in the reconstruction and restoration of cities. Vestn. MGSU Proc. Mosc. State Univ. Civ. Eng. 2019, 14, 417-426. [CrossRef]

22. Nocca, F. The Role of Cultural Heritage in Sustainable Development: Multidimensional Indicators as Decision-Making Tool. Sustainability 2017, 9, 1882. [CrossRef]

23. Slepnev, M.; Marshalkovich, A.; Papush, P. Creating protected areas in the urban environment, corresponding to the "Smart City" formation concept. The way to sustainable development of urban ecosystems. IOP Conf. Ser. Mater. Sci. Eng. 2018, 365, 022034. [CrossRef]

24. Telichenko, V.; Benuzh, A.; Mochalov, I. Landscape Architecture and green spaces in Russia. MATEC Web Conf. 2017, 117, 00164. [CrossRef]

25. McConnell, W.J.; Viña, A. Interactions between Food Security and Land Use in the Context of Global Change. Land 2018, 7, 53. [CrossRef]

26. Shcherbina, E.; Gorbenkova, E. Smart city technologies for sustainable rural development. IOP Conf. Ser. Mater. Sci. Eng. 2018, 365, 022039. [CrossRef]

27. Shcherbina, E.V.; Gorbenkova, E.V. Cluster Approach in Rural Settlement Development. IOP Conf. Ser. Mater. Sci. Eng. 2020, 753, 032086. [CrossRef]

28. Zhao, Y.; Leng, H.; Sun, P.; Yuan, Q. Application and Validation of a Municipal Administrative Area Spatial Zoning Model in Village-Town System Planning. Sustainability 2019, 11, 1855. [CrossRef]

29. Honeck, E.; Moilanen, A.; Guinaudeau, B.; Wyler, N.; Schlaepfer, M.A.; Martin, P.; Sanguet, A.; Urbina, L.; von Arx, B.; Massy, J.; et al. Implementing Green Infrastructure for the Spatial Planning of Peri-Urban Areas in Geneva, Switzerland. Sustainability 2020, 12, 1387. [CrossRef]

30. Egidi, G.; Halbac-Cotoara-Zamfir, R.; Cividino, S.; Quaranta, G.; Salvati, L.; Colantoni, A. Rural in Town: Traditional Agriculture, Population Trends, and Long-Term Urban Expansion in Metropolitan Rome. Land 2020, 9, 53. [CrossRef]

31. Davidenko, P.; Menshikova, E.; Gorbenkova, E. "Smart settlements": The development concept in a new socio-economic and informatiologic conditions. IOP Conf. Ser. Mater. Sci. Eng. 2018, 365, 022050. [CrossRef]

32. Gorbenkova, E.V. Factors shaping the development of rural settlement. Proc. Mosc. State Univ. Civ. Eng. 2019, 14, 805-818. [CrossRef]

33. Mezentsev, S.D. Methodological approaches to the study of urban planning. Proc. Mosc. State Univ. Civ. Eng. 2012, 8, 26-33. [CrossRef]

34. Kubeckaya, L.I.; Kudryavtseva, N.O. Historical and Genetic Features of Settlement and Urban Structure of Russian Settlements of the North as a Reflection of the National Identity and Cultural Heritage of Russia. City Town Panning 2019, 5, 36-48.

35. Kudryavtseva, N.O.; Kubeckaya, L.I. Historical-Genetic Interconnections of the Pskov-Novgorod Settlement System. Acad. Archit. Constr. 2018, 1, 44-52. [CrossRef]

36. Telichenko, V.I.; Shcherbina, E.V. Social-Natural-Technogenic System of Sustainable Environment of Vital Activity. Ind. Civ. Eng. 2019, 6, 5-12. [CrossRef]

37. Alekseev, A.I.; Safronov, S.G. Subsidiary Household Farming in Russian Regions in the Late 20th-Early 21st Centuries. Reg. Res. Russ. 2018, 8, 364-374. [CrossRef]

38. Diaz-Sarachaga, J.M. Analysis of the Local Agenda 21 in Madrid Compared with Other Global Actions in Sustainable Development. Int. J. Env. Res. Public Health 2019, 16, 3685. [CrossRef] 
39. Shcherbina, E.; Gorbenkova, E. Factors Influencing the Rural Settlement Development. IFAC Pap. 2019, 52, 231-235. [CrossRef]

40. Gorbenkova, E.; Shcherbina, E.; Belal, A. Rural Areas: Critical Drivers for Sustainable Development. IFAC Pap. 2018, 51(30), 786-790. [CrossRef]

41. Antipova, E.A.; Shavel, A.N.; Zaprudskij, I.I. Economic and geographical and socio-economic differences of regions of the Republic of Belarus as a basis for improvement of administrative-territorial division. J. Belarusian State Univ. Geogr. Geol. 2019, 1, 3-21. [CrossRef]

42. Antipova, E.A. Demographic development of republic of Belarus in XXI century: Trends, regional differences, problems. Population 2016, 1, 5-15.

43. World Urbanization Prospects 2018. Available online: https://population.un.org/wup/Country-Profiles/ (accessed on 1 March 2020).

44. Buchecker, M.; Frick, J. The Implications of Urbanization for Inhabitants' Relationship to Their Residential Environment. Sustainability 2020, 12, 1624. [CrossRef]

45. Pazhuhan, M.; Shahraki, S.Z.; Kaveerad, N.; Cividino, S.; Clemente, M.; Salvati, L. Factors Underlying Life Quality in Urban Contexts: Evidence from an Industrial City (Arak, Iran). Sustainability 2020, 12, 2274. [CrossRef]

46. Gibas, P.; Majorek, A. Analysis of Land-Use Change between 2012-2018 in Europe in Terms of Sustainable Development. Land 2020, 9, 46. [CrossRef]

47. Mazur, L.N. Methods of Historical Research Book Title, 2nd ed.; Ural State University: Ekaterinburg, Russia, 2010; 608p.

48. Mazur, L.N. Quantitative historical models: Types, possibilities, and limitations. Russ. Hist. 2011, 2, 142-149.

49. Fomkina, A.A. Transformation of rural settlement system in the old-developed Non-Chernozem area from the end of the 19th to the beginning of the 21st century. Vestn. Mosk. Univ. Seriya Geogr. 2017, 5, 68-75.

50. National Statistical Committee of the Republic of Belarus. Available online: https://www.belstat.gov.by/en/ (accessed on 11 September 2019).

51. Starye karty Belarusi. Available online: http://www.etomesto.ru/ (accessed on 11 September 2019).

52. Scheme of Integrated Territorial Organization of Mogilev Region. Available online: http://mogilev.mogilevregion.by/uploads/files/Ekologicheskij-doklad-Mogilevskij-rajon.pdf (accessed on 11 September 2019).

53. Belorusskie derevni, sozhzhjonnye v gody Velikoj Otechestvennoj vojny. Available online: http://db.narb.by/ search/?title=\&titles=new\&region=8\&district=182\&year=1944 (accessed on 11 September 2019).

(C) 2020 by the authors. Licensee MDPI, Basel, Switzerland. This article is an open access article distributed under the terms and conditions of the Creative Commons Attribution (CC BY) license (http://creativecommons.org/licenses/by/4.0/). 